\title{
Cellulase, Pectinase, and Xylanase Production by Listeria sp. ISH 16 using Coffee Pulp Waste Medium
}

\author{
Ummi Wasilah, Kahar Muzakhar, and Purwatiningsih \\ Department of Biology, University of Jember, Jember \\ e-mail:kaharmzk@unej.ac.id
}

\begin{abstract}
In this study, microbial utilization of coffee pulp waste to produce three carbohydrases (cellulase, pectinase, and xylanase) has been investigated. An isolate Listeria sp. ISH-16 which grown in liquid medium containing $0.5 \%$ coffee pulp alkali extract can grow well with density of reach $10^{7} \times 58.5$ cell $/ \mathbf{m L}$. Further, the culture can optimum produced of pectinase after 72 hours incubation at $37^{\circ} \mathrm{C}$, but for cellulase and xylanase longer 84 hours incubation needed. The harvested of crude pectinase, cellulase and xylanase had activity $0.15,0.23$, and $0.61 \mathrm{unit} / \mathrm{ml}$ after dialysis, respectively. All enzymes stable at a range of $\mathrm{pH} 4-5.5$, but they work optimum at different $\mathrm{pH}$. Of each enzyme pectinase, cellulase, and xylanase work optimum at pH 5, 4.5, and 5.5. based on these results, it may be adopted as a strategy to produce enzymes with low cost so that further investigation such as large scale and purification enzyme is needed.
\end{abstract}

Keywords - Carbohydrase, Cellulase, Coffee Pulp, Pectinase, Xylanase.

\section{INTRODUCTION}

$\mathrm{T}$ HE use of enzymes in industries such as food, textile, detergent, agriculture, chemicals, and pharmaceuticals is increasing rapidly because of low cost, fast process, nontoxic and eco-friendly characteristics. According to industrial enzyme market global market demand for industrial purposes, estimated about USD 5.9 billion in 2020 and projected to reach USD 8.7 billion by 2026 and is expected to expand at a compound annual growth rate (CAGR) of approximately $6.5 \%$ over the period from 2020 to 2026 [1]. Further, the microbial enzyme is preferred, since this simplifies downstream processing, hence further lowering costs, so that the selection of substrate is important to produce an enzyme easily and at a low-cost [2]. The utilization of coffee pulp biomass can be an alternative.

It was known that coffee pulp waste is potential biomass which the main polysaccharide components are 57.9\% cellulose, 21, 63\% hemicellulose, $5.21 \%$ lignin, and $2.28 \%$ pectin, $12.4 \%$ reducing sugar and $2 \%$ non-reducing sugar [34]. These polysaccharides can be used as a bacterial growth media for enzyme production. Previous studies reported that coffee pulp can be used as a substrate to produce $\alpha$-amylase from Bacillus amyloliquefaciens yielding $550 \mathrm{U} / \mathrm{g}$ after 120 hours of incubation [5]. According to Ubaidillah et al, the coffee pulp is a good material for Pestalotiosis sp. VM9 and Aspergillus sp. VTM5 to produce sugars which can be used as substrate for single cell production [6].
It was reported that carbohydrase group is the most enzyme frequently used in food industry [7]. More over, predicted in period of 2020-2026 the demand of the enzyme will increase significantly so that some efforts and low cost or costeffectiveness strategy must be highly considered [1]. The utilization of a huge source coffee pulp waste is may one important thing to reduce cost production. In the other hand, to discover a new-sources of carbohydrases, investigation is needed.

In this paper, the microbial utilization of coffee pulp to produce carbohydrase (cellulase, pectinase and xylanase) using cellulolytic bacteria Listeria sp [8-9].

\section{METHOD}

\section{A. Preculture and Optimum Growth Analysis of Listeria Sp. ISH 16 in Coffee Pulp Alkali Extract Medium}

The Listeria sp. ISH 16 was obtained from previous research, grown in nutrient agar containing $0.5 \%$ coffee pulp alkali extract (CPAE) without any nutrient added as preculture $[8,10]$. CPAE was prepared from 100 grams powdered coffee pulp suspended to distillate water containing $1 \mathrm{M} \mathrm{NaOH}$. The suspension was stirred for 24 hours at $25^{\circ} \mathrm{C}$. The filtrate was obtained by filtering on buchner using filter paper. The filtrate was adjusted to $\mathrm{pH} 7$ using acetic acid. The filtrate was made to $60 \%$ in ethanol and the precipitate as CPAE was obtained after centrifugation at $10.000 \mathrm{rpm}$ for 10 minutes. This pellet dried at $55^{\circ} \mathrm{C}$ and was used for Listeria sp. ISH 16 medium to growth and produce carbohydrase. To analyse optimum growth of Listeria sp. ISH 16, the examination was done by culturing of preculture to broth medium containing $0.5 \%$ CPAE. for this step, one ose was inoculed to medium. Then the culture incubated at $25^{\circ} \mathrm{C}$ on a shaker with speed $120 \mathrm{rpm}$, and growth of cell density (cell $/ \mathrm{mL}$ ) monitored and calculated periodically every 24 hours.

\section{B. Cellulase, Pectinase and Xylanase Production using CPAE based Broth Medium}

In this step, time of incubation for carbohydrase (cellulase, pectinase and xylanase) production based on broth CPAE medium must be first optimized. For this purpose, $45 \mathrm{~mL}$ broth CPAE $0.5 \%$ was inoculated with $5 \mathrm{~mL}$ Listeria $\mathrm{sp}$. ISH $16\left(58,5 \times 10^{7} \mathrm{cel} 1 / \mathrm{mL}\right)$, incubated for 7 days at $25^{\circ} \mathrm{C}$, and shaken $120 \mathrm{rpm}$. And then, optimum enzymes production was measured periodically every 12 hours base on enzyme 
The $6^{\text {th }}$ International Seminar on Science and Technology (ISST) 2020

July $25^{\text {th }} 2020$, Institut Teknologi Sepuluh Nopember, Surabaya, Indonesia

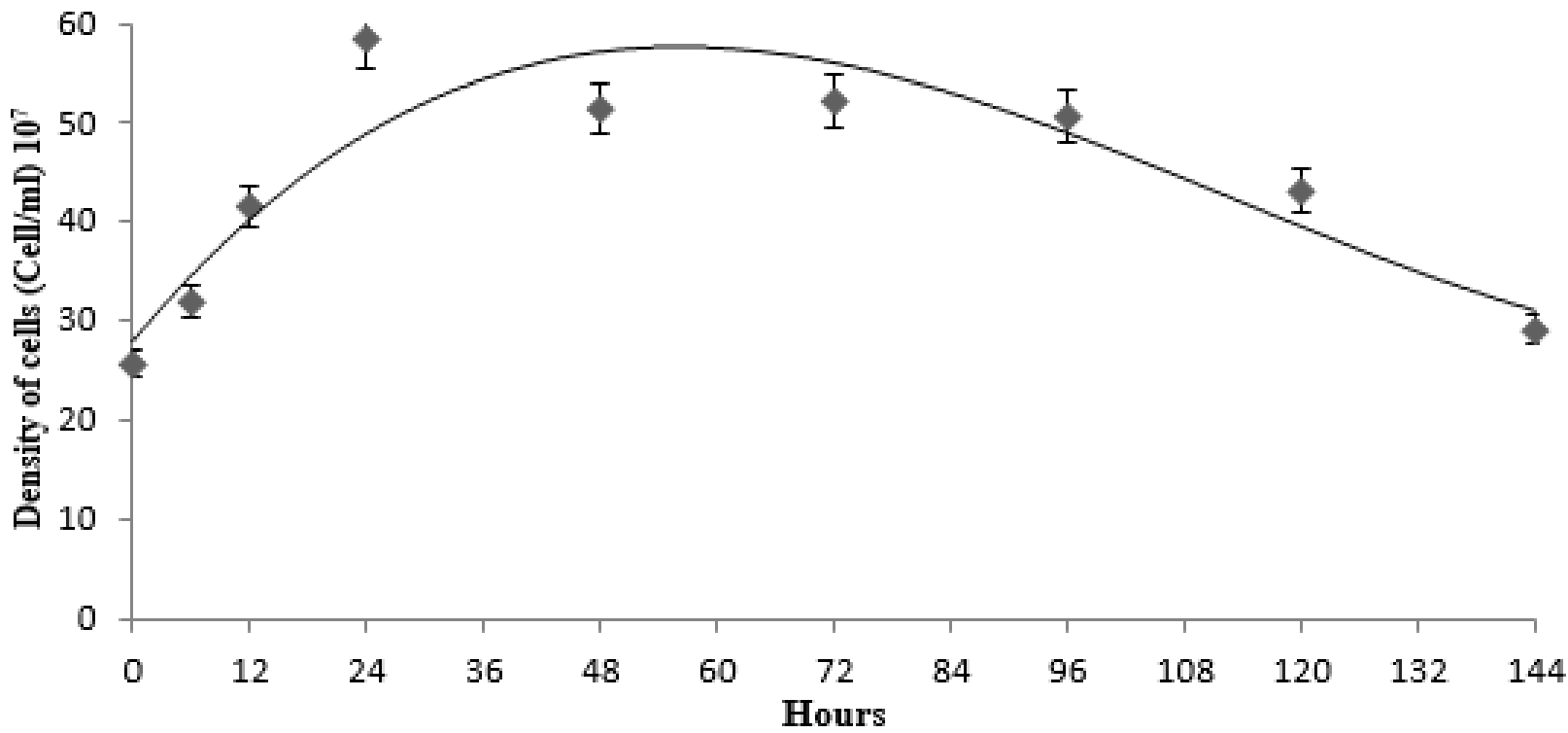

Figure 1. The growth curve of Listeria sp. ISH-16.

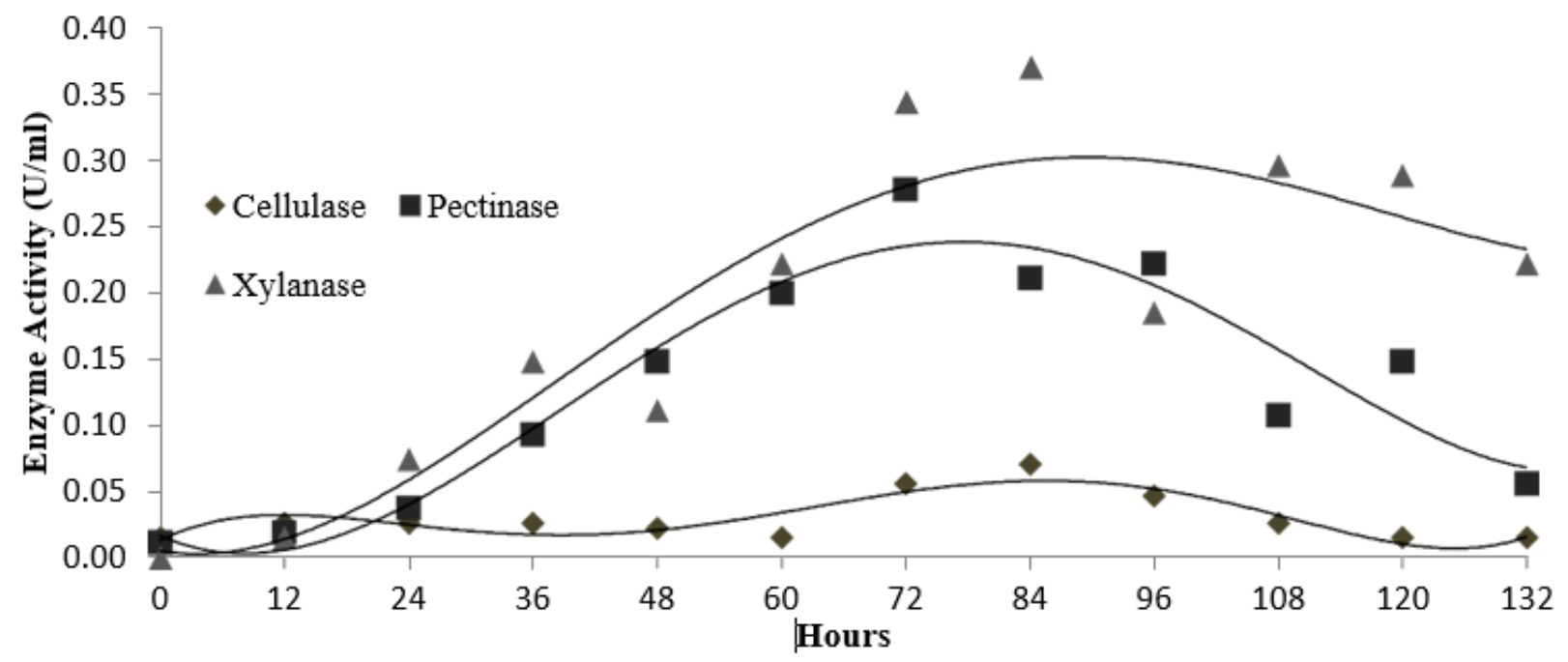

Figure 2. Optimization of the production of cellulase, pectinase, and xylanase by Listeria sp. ISH-16.

activity. For measuring the activities of enzymes, the reducing sugar produced as were quantified described by Somogy-Nelson method [11].

The enzymes activity was assayed in $1 \%$ substrate containing acetate buffer $20 \mathrm{mM}$ of $\mathrm{pH}$. One hundred microliter of enzyme was added and incubated at $37^{\circ} \mathrm{C}$ for 2 hours enzymes reaction was stopped by adding $500 \mu \mathrm{L}$ somogy and than boiled for 15 minutes. After cooling at room temperature, $500 \mu \mathrm{L}$ Nelson solution and $2.5 \mathrm{~mL} \mathrm{H}_{2} \mathrm{O}$ were added, centrifuged at $8000 \mathrm{rpm}$ for 10 minutes. And then, the reducing sugar content of supernatant was measured at absorbance $500 \mathrm{~nm}$ compared with control.

\section{Stability and Optimum $\mathrm{pH}$}

Before examine the stability and optimum $\mathrm{pH}$ the crude enzyme was dialysed in $20 \mathrm{mM}$ acetate buffer $\mathrm{pH}$ 5. This step was done on cellulose dialysis membrane tube $14 \mathrm{kDa}$ for 24 hours at $4^{\circ} \mathrm{C}$. The buffer was changed every 12 hours.

Optimum and stability $\mathrm{pH}$ of cellulase, pectinase and xylanase on activities were determined at a range $\mathrm{pH} 3$ to 8 using $20 \mathrm{mM}$ acetate and phosphate buffer. Acetate buffer at a range $\mathrm{pH} 3$ to 5.5 and phosphate buffer 6 to 8 were used. The optimum $\mathrm{pH}$ of enzymes activity analysis was assayed by measuring of sugar reducing as describe above. At concentration $1 \%$ of carboxymethyl cellulose (CMC), citrus pectin and xylan substrate on $20 \mathrm{mM}$ buffer were used for assaying of cellulase, pectinase and xylanase activities.

\section{RESULT AND DISCUSSION}

\section{A. Optimum Growth Analysis of Listeria sp. ISH 16 in Coffee Pulp Alkali Extract Medium}

The investigation showed that an isolate Listeria sp. can grow on broth medium containing $0.5 \%$ coffee alkaline extract. The growth of microorganisms depends on the source of nutrients in the form of carbon and nitrogen, founded in the environments [12]. Shown at Figure 1, an exponential growth starting from the 12 to 24 hours incubation was achieved by Listeria sp. The increasing growth with density reached up to 
The $6^{\text {th }}$ International Seminar on Science and Technology (ISST) 2020

July $25^{\text {th }} 2020$, Institut Teknologi Sepuluh Nopember, Surabaya, Indonesia

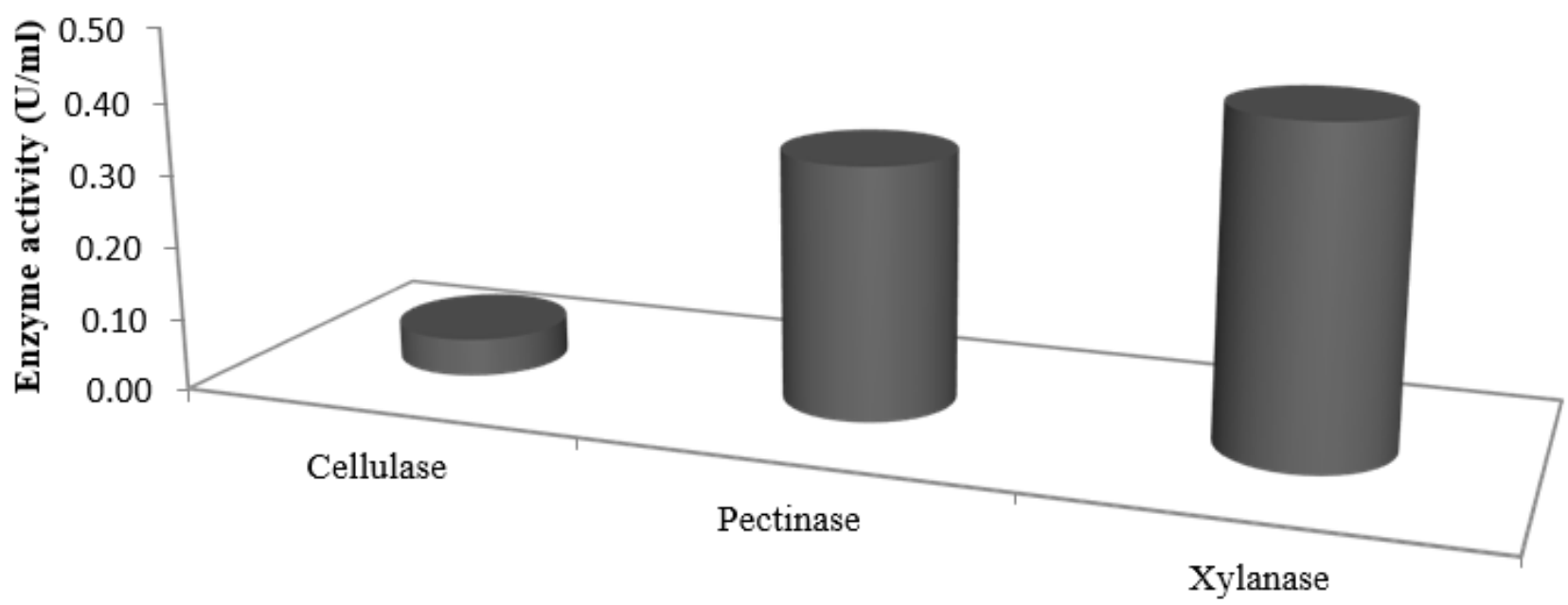

Figure 3. Enzyme activity after 72 hours incubation.

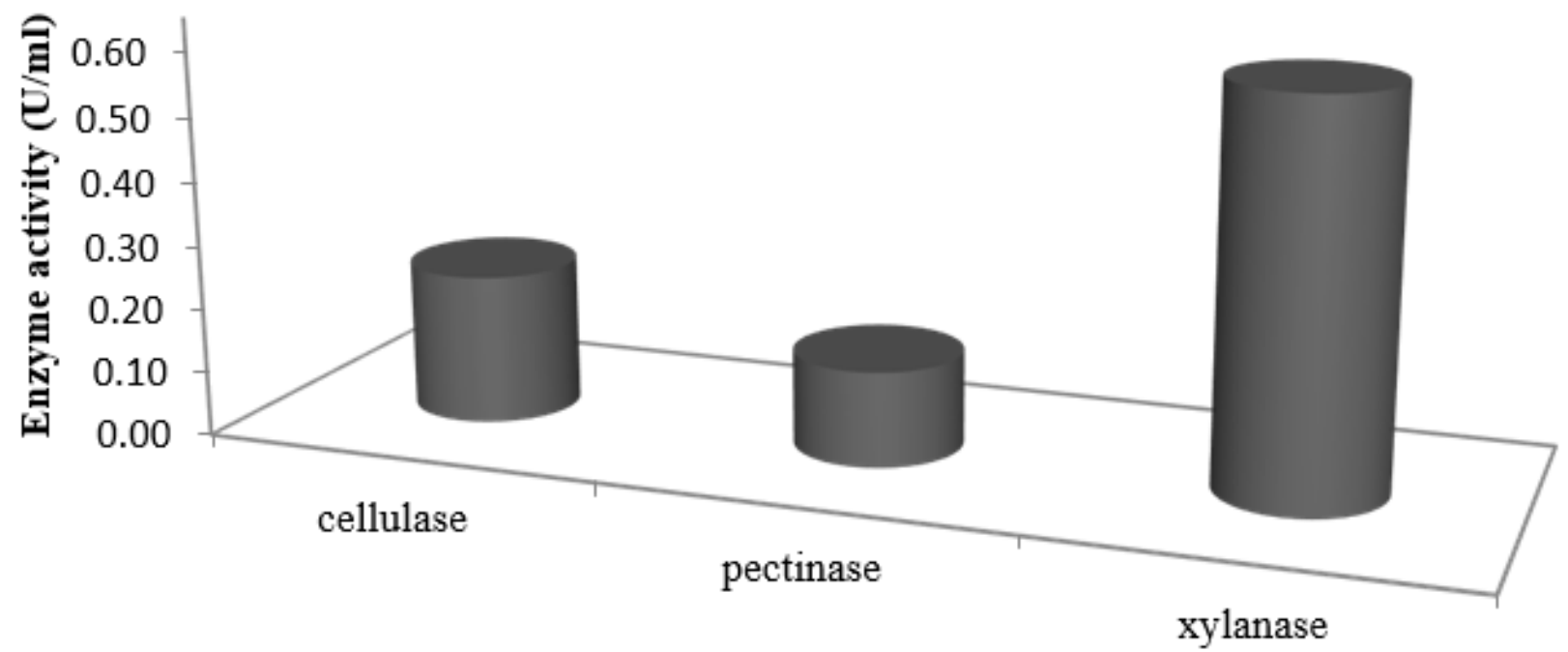

Figure 4. Enzyme activity of cellulase, pectinase and xylanase after dialysis.

$10^{7} \times 58.5$ cell $/ \mathrm{mL}$ proved that this isolate able to utilize carbon and nitrogen source from coffee pulp waste without any nutrient added. Stationary phase was seen at 48 to the 96 hours and growth decreased after 120 to 144 hours (Figure 1). In this research it has been found that the best growth is at 24hour incubation, where an exponential growth phase occurs. This incubation period is used to determine the amount of inoculum needed in enzyme production.

B. Optimization of The Production of Cellulase, Pectinase, and Xylanase by Listeria sp. ISH 16

Optimization of enzyme production is carried out by cultivating microorganisms in liquid nutrient broth. This involves growing carefully selected microorganisms in closed vessels that contain containing a high concentration of oxygen and a rich of nutrients. As the microorganisms break down the nutrients, they release the enzymes into a solution [13]. When an organism grows in liquid media, it utilizes the components of the medium and excreted by-products of bacterial metabolism into the medium such as various enzymes [14]. This technique was best for microorganisms such as bacteria which required high humidity and was easier product purification [15]. Many industrial enzymes can be produced using this process. According to Manpreet, bacteria would grow better in media had high water content [16]. This was related to the growth of bacteria on the surface while the fungus could penetrate the substrate using mycelium. Thus, it would be more suitable to be grown on solid media.

The method used to measure reducing sugars in enzyme activity was using the Somogy-Nelson method. The principle of the Somogy-Nelson method was that reducing sugars would reduce $\mathrm{Cu} 2+$ into $\mathrm{Cu}+, \mathrm{Cu}+$ would reduce arsenomolybdate compounds to form a greenish-blue color [11]. The incubation time affected the number of isolates ISH- 16 on the alkaline media of coffee pulp to produce crude enzymes. Enzyme activity produced by a microorganism was affected by the incubation time depending upon the type of microorganism and other culture conditions such as inoculum size, $\mathrm{pH}$, and temperature [17-18]. Other studies mention that fermentation time has a profound effect on the formation of microbial products [19]. The optimum time for enzyme production was used as the time for large-scale enzyme production.

Optimization of enzyme crude production was conducted to find out optimum incubation duration to produce cellulase, 


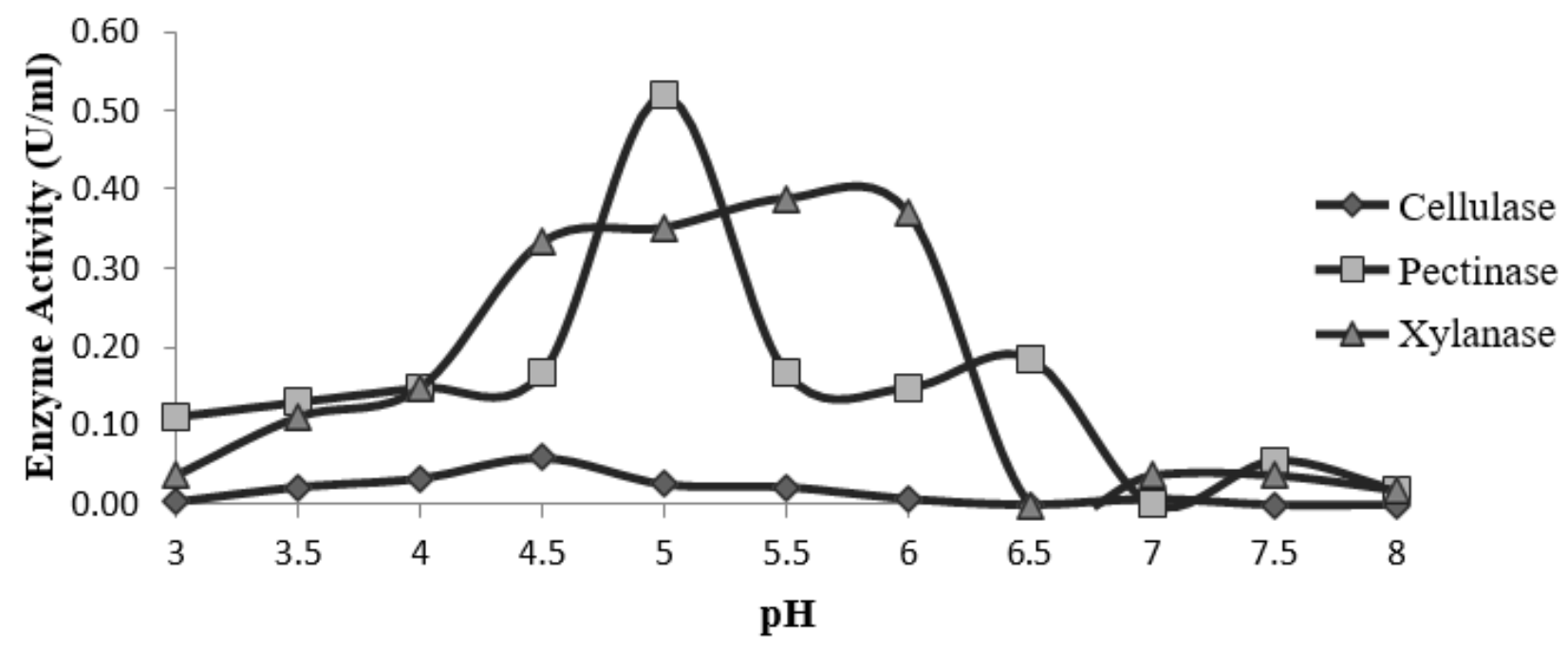

Figure 5. Enzyme activity of optimum $\mathrm{pH}$.

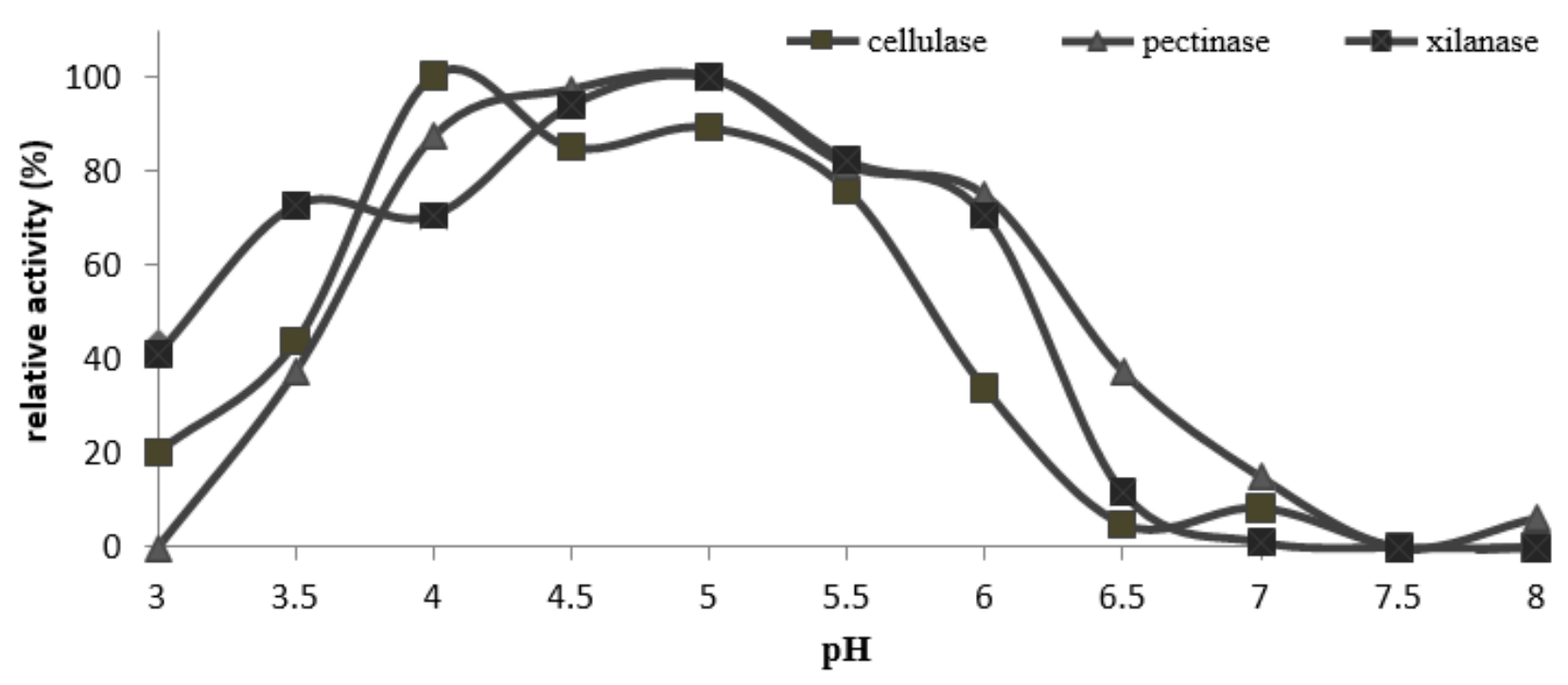

Figure 6. Relative activity of $\mathrm{pH}$ stability.

pectinase, and xylanase enzymes. The optimum incubation duration for each enzyme had a different time (Figure 2). In this research, an isolated ISH-16 could produce cellulase with optimum value at 84 hours with the highest activity of

$0.07 \mathrm{U} / \mathrm{mL}$. According to Sirisena and Manamendra, Listeria sp. could produce cellulase with a concentration of $1.8 \mathrm{mmol} / \mathrm{l}$ using cellulose substrate and $1.5 \mathrm{mmol} / \mathrm{l}$ with CMC substrate [9]. Crude enzyme activity produced by Listeria sp. was considered high if compared to other species. According to Asem, A. aneurinilyticus exhibited cellulase activity (FPase) $0.62 \mathrm{U} / \mathrm{mL}$ at 120 hours, while Aneurinibacillus sp. and Serratia rubidaea, which had activities of 0.53 and $0.5 \mathrm{U} / \mathrm{mL}$ at 48 and 96 hours, respectively [20].

The optimum pectinase incubation duration was 72 hours with the highest activity $0,28 \mathrm{U} / \mathrm{mL}$. Other research mentions that Bacillus circulans could produce total activity $256 \mathrm{U} / \mathrm{mL}$ pectinase by Submerged fermentation method using galactose substrate [21]. The optimum incubation duration for xylanase was 84 hours with $0.37 \mathrm{U} / \mathrm{ml}$ activity. There was no research on Listeria sp. to produce the enzymes pectinase and xylanase. If it was compared to the research conducted by Asem using $S$. Rubidaea, Aneurinibacillus aneurinilyticus, and Bacillus aureus has xylanase activity of $6.15 \mathrm{U} / \mathrm{mL}$ at 72 hours, $4.12 \mathrm{U} / \mathrm{mL}$ at 96 hours and $3.05 \mathrm{U} / \mathrm{ml}$ at 48 hours, respectively [20].

\section{Large Scale Production}

Large scale production is obtained from optimization tests that have been done before. Large scale production uses the most optimum activity and with a relatively short time of incubation at 72 hours (Figure 3). Crude enzymes sho wed that the xylanase activity was higher than the others $(0.44$ $\mathrm{U} / \mathrm{mL}$ with specific activity of $0.011 \mathrm{U} / \mathrm{mg}$ ). followed by pectinase $(0.34 \mathrm{U} / \mathrm{mL}$ with specific activity of $0.009 \mathrm{U} / \mathrm{mg})$ and cellulase $(0.05 \mathrm{U} / \mathrm{mL})$ with specific activity of 0.0013 $\mathrm{U} / \mathrm{mg}$ ), respectively (Table 3). The results of large-scale production indicate that enzyme activity has increased compared to optimization.

\section{Dialysis}

The enzyme activity that has been dialyzed has increased compared to a crude enzyme. During the process of dialysis 
The $6^{\text {th }}$ International Seminar on Science and Technology (ISST) 2020

July $25^{\text {th }}$ 2020, Institut Teknologi Sepuluh Nopember, Surabaya, Indonesia

Table 1.

Comparison of cellulase enzyme activity at various stages of purification

\begin{tabular}{lllllllll}
\hline \hline Purification steps & Volume & $\begin{array}{l}\text { Activity } \\
(\mathrm{U} / \mathrm{mL})\end{array}$ & $\begin{array}{l}\text { Total } \\
(\mathrm{U} / \mathrm{mL})\end{array}$ & $\begin{array}{l}\text { Activity } \\
\text { Abs } 280 \mathrm{~nm}\end{array}$ & $\begin{array}{l}\text { Total Abs. } \\
280\end{array}$ & $\begin{array}{l}\text { Specific } \\
\text { Activity/Abs. } \\
\text { nm (U/mg) }\end{array}$ & 280Yield (\%) & Purification Fold \\
\hline Crude enzyme & 473 & 0,05 & 23,65 & 0,193 & 91,29 & 0,0013 & 100 & 1,00 \\
Dialysis & 207 & 0,23 & 47,61 & 0,14 & 28,98 & 0,0082 & 201,31 & 6,34 \\
\hline \hline
\end{tabular}

Table 2 .

Comparison of pectinase enzyme activity at various stages of purification

\begin{tabular}{|c|c|c|c|c|c|c|c|c|}
\hline Purification Steps & Volume & $\begin{array}{l}\text { Activity } \\
\text { (U/Ml) }\end{array}$ & $\begin{array}{l}\text { Total } \\
\text { (U/Ml) }\end{array}$ & $\begin{array}{l}\text { Activity } \\
\text { Abs } 280 \mathrm{~nm}\end{array}$ & $\begin{array}{l}\text { Total Abs. } \\
280\end{array}$ & $\begin{array}{l}\text { Specific } \\
\text { Activity/Abs. } \\
280 \mathrm{~nm}(\mathrm{U} / \mathrm{mg})\end{array}$ & Yield (\%) & Purification Fold \\
\hline Crude enzyme & 473 & 0,34 & 160,82 & 0,193 & 91 & 0,009 & 100 & 1,00 \\
\hline Dialysis & 207 & 0,15 & 31,05 & 0,14 & 28,98 & 0,005 & 19,3 & 0,61 \\
\hline
\end{tabular}

Table 3 .

Comparison of xylanase enzyme activity at various stages of purification

\begin{tabular}{|c|c|c|c|c|c|c|c|c|}
\hline Purification steps & Volume & $\begin{array}{l}\text { Activity } \\
\text { (U/mL) }\end{array}$ & $\begin{array}{l}\text { Total } \\
(\mathrm{U} / \mathrm{mL})\end{array}$ & $\begin{array}{l}\text { Activity } \\
\text { Abs } 280 \mathrm{~nm}\end{array}$ & $\begin{array}{l}\text { Total Abs. } \\
280\end{array}$ & $\begin{array}{l}\text { Specific } \\
\text { Activity/Abs. } \\
280 \mathrm{~nm}(\mathrm{U} / \mathrm{mg})\end{array}$ & Yield (\%) & Purification Fold \\
\hline Crude enzyme & 473 & 0,44 & 208,12 & 0,193 & 91 & 0,011 & 100 & 1,00 \\
\hline Dialysis & 207 & 0,61 & 126,27 & 0,14 & 28,98 & 0,022 & 60,67 & 1,91 \\
\hline
\end{tabular}

in Figure 4, the unwanted protein in the dialysis tubing moves from high concentration to low concentration. As the volume of the solution in the dialysis tubing decreases, the enzyme activity is increased [22]. Cellulase activity was $0.23 \mathrm{U} / \mathrm{mL}$ with specific activity $0.0082 \mathrm{U} / \mathrm{mg}$ and purification fold 6.34 (Table 1). Pectinase activity was $0.15 \mathrm{U} / \mathrm{mL}$ with a specific activity of $0,005 \mathrm{U} / \mathrm{mg}$ and purification fold 0.61 , respectively (Table 2). While xylanase activity was 0.61 $\mathrm{U} / \mathrm{mL}$ with a specific activity $0.022 \mathrm{U} / \mathrm{mg}$ and purification fold 1.91 (Table 3). Dialysis can remove contaminants with lower molecular weight than enzyme molecules. The principle of dialysis is the transfer of smaller molecules by passing through a semi-permeable membrane by diffusion [23]. Sample molecules larger than the membrane pores will be retained on the sample side of the membrane, but small molecules and buffer pass freely through the membrane, reducing the concentration of these molecules in the sample [24]. Recent reports mention that Listeria sp. cellulolytic bacteria that are incubated in 72 hours could produce cellulase enzymes with an enzyme activity of $0.078 \mathrm{U} / \mathrm{ml}$ using CMC substrate [8]. There was no research on Listeria sp. to produce the enzymes pectinase and xylanase. when compared with the Navasivayam study using Bacillus cereus, Maximum pectinase enzyme production (44 U/mL) [25]. $B$. cereus produces a pectinase higher than this study because the purification used by the research is more complexly using ammonium sulfate precipitation and dialysis. Ho and Heng used Bacillus sp. bacteria and barley media husk enzyme activity produced were $4.947 \mathrm{U} / \mathrm{mL}$ at 48 hours incubation [26]. This proves that Bacillus sp. can produce xylanase enzymes higher than Listeria sp. ISH-16 using Barley husk media. A comparison of enzyme activities at each stage is presented in tables 1,2 , and 3 .

\section{E. Characterization (Stability and Optimum pH)}

Figure 5 depicts the effect of different $\mathrm{pH}$ on the production of enzymes target by isolate ISH-16. The maximum production of cellulase was obtained at $\mathrm{pH} 4.5$ with activity $0.06 \mathrm{U} / \mathrm{ml}$ and stable more than $70 \%$ at $\mathrm{pH} 4.0$ 5.5 (Figure 6). These findings were similarly reported by
Yang et al, where a Bacillus substilis isolate from Tibetan pig's intestine were exhibited when at $\mathrm{pH} 4 \mathrm{CMCase}$ activity showed a minimum activity of $0.5 \mathrm{U} / \mathrm{mL}$ while at $\mathrm{pH} 5.5$ maximum activity is obtained $2.41 \mathrm{U} / \mathrm{mL}$ [27]. Vatanparast $e t$ $a l$, reported that optimum $\mathrm{pH}$ for cellulase activity from the larval midgut of $R$. ferrugineus was obtained at $\mathrm{pH} 5.0$ and 6.0 [28]. The best $\mathrm{pH}$ for the pectinase producers was $\mathrm{pH} 5$ with activity $0.52 \mathrm{U} / \mathrm{mL}$ and stable in a $\mathrm{pH}$ range 4.0-6 (Figure 6). Decrease enzyme activity on both sides of the optimum $\mathrm{pH}$ due to enzymes undergoing a change in secondary or tertiary structure caused by changes in $\mathrm{pH}$ that are too low or vice versa. Extreme $\mathrm{pH}$ will damage the catalytic site of the enzyme so that it cannot be bound to the substrate. Robinson mentions that enzymes have a characteristic optimum $\mathrm{pH}$ at which the speed of the catalyzed reaction is maximum, and above and below the speed decreases [29].

According Vatanparast et al reported that pectinase enzymes from the midgut of $R$. ferrugineus, hydrolyzed substrate in a pH range 6.0-7.0 [28]. Orange peel as a substrate at the concentration of $1 \%$ with a $\mathrm{pH}$ of 7.0 was found to be optimum for pectinase production by Bacillus sp. The xylanase was found to be active at range of $\mathrm{pH}$ values between 3.5 to 6.0 with maximum $\mathrm{pH}$ of $5.5(0.41 \mathrm{U} / \mathrm{mL})$. The enzyme activity gradually enhanced with increased $\mathrm{pH}$ from 3.5 to 6.0 and decreased in alkaline condition from $\mathrm{pH}$ 6.5-8.0. This study was similarly reported by Seo et al, where a $B$. licheniformis isolate from the rumen of a Korean goat exhibited a maximal xylanase activity of $1.08 \mathrm{U} / \mathrm{mL}$ at $\mathrm{pH} 5.0$ [30]. Other studies mention that xylanase produced by Aspergillus sp. using coffee pulp waste substrate optimal at $\mathrm{pH} 5$ and stable in the $\mathrm{pH}$ range of 3-6.5 [31]. This result indicates that the target enzyme can work actively in the acidic $\mathrm{pH}$ range and its activity decreases dramatically in alkaline or basic $\mathrm{pH}$.

\section{CONCLUSION}

Listeria sp. ISH-16 could has the highest xylanase and cellulase activity $0.37 \mathrm{U} / \mathrm{mL}, 0.07 \mathrm{U} / \mathrm{mL}$ in 84 hours of 
The $6^{\text {th }}$ International Seminar on Science and Technology (ISST) 2020

July $25^{\text {th }} 2020$, Institut Teknologi Sepuluh Nopember, Surabaya, Indonesia

incubation time, respectively. Whereas pectinase activity $0.28 \mathrm{U} / \mathrm{mL}$ in 72 hours of incubation time. The harvested of crude cellulase had activity was $0.23 \mathrm{U} / \mathrm{mL}$ with a specific activity of $0.0082 \mathrm{U} / \mathrm{mg}$ and purification fold 6.34 , pectinase had highest activity $0.15 \mathrm{U} / \mathrm{mL}$ with a specific activity of $0,005 \mathrm{U} / \mathrm{mg}$ and purification fold 0.61. Xylanase had an activity of $0.61 \mathrm{U} / \mathrm{mL}$ with a specific activity $0.022 \mathrm{U} / \mathrm{mg}$ and purification fold 1.91 after dialysis. Cellulase worked optimally at $\mathrm{pH}$ at 4.5 and was stable at $\mathrm{pH} 4-5.5$. Pectinase showed to be more stable at 4-5.5 with optimum $\mathrm{pH}$ was 5 . Xylanase had an optimal $\mathrm{pH}$ at 6 and was stable at $\mathrm{pH} 4.5-$ 5.5. These results could be as pre-indicator that Listeria sp. able to produce some target enzymes. However, to increase enzyme activity, further purification is needed.

\section{ACKNOWLEDGMENT}

This research was funded by Direktorat Jenderal Penguatan Riset dan Pengembangan, Kementerian Riset dan Teknologi /Badan Riset dan Inovasi Nasional, under Penelitian Thesis Magister scheme, 2020

\section{REFERENCES}

[1] Industrial enzymes market. "Industrial enzyme market by type (carbohydrases, proteases, non-starch polysaccharides \& nucleases, others types), source, application (food \& beverage, feed, bioethanol, detergents, pulp \& paper, textiles \& leather, wastewater, treatment, other applications), form, and region- global forecast to 2026 https://www.marketsandmarkets.com/Market-Reports/industrialenzymes-market-237327836.html. Accessed on 6 July 2020

[2] A. Tanriseven and S. Dogan. "Immobilization of Pectinex Ultra SP- L to Produce Fructooligosaccharides". Enzyme Mycrob. Technol, Vol .36 , pp. 550-554, 2001.

[3] S.R. Juliastuti, T. Widjaja, A. Altway, V.A. Sari, D. Arista, and T. Iswanto. "The effect of microorganism on coffee pulp pretreatment as a source of biogas production". MATEC Web of Conferences 156, 03010, 2018. https://doi.org/10.1051/matecconf/201815603010.

[4] N. K. Blinova, M. Sirotiak, A. Bastosova and M. Soldan. Review: "Utilization of waste from coffee production". Research paper, Vol .25, no. 40,2017

[5] T. Selvankumar., M. Govarthanan., M. Govindaraju. "Production of Extracellular $\alpha$-amylase enzyme by Bacillus amyloliquefaciens using coffee pulp waste as substrate". An Indian Journal, Vol. 4, no.3, pp. $156-159,2010$

[6] S. Ubaidillah and K. Muzakhar. "produced under solid state fermentation by Pestalotiosis sp. VM9 and Aspergillus sp. VTM5, and its efficiency as medium for single cel protein Saccharomyces cerevisiae". IOP Conf. Series, Vol. 546, 2019.

[7] F. J. Contesini., J. D. A. Figuera., H. Y. Kawaguti., P. C. B. Fernandes, P. D. O, Carvalho., M. D. G. Nascimento., H. H. Sato." Potential Applications of Carbohydrases Immobilization in the Food Industry". Review. International Journal of Molecular Science, Vol. 14. pp. 1335 1369, 2013.

[8] Azizah. "Skrening bakteri selulolitik dari sistem pencernaan Hypothenemus hampei Ferr dan purifikasi enzim yang dihasilkan". Thesis. Jember: Jember University Graduate Program, 2019.

[9] D. M. Sirisena, and T. P. Manamendra. "Isolation and characterization of cellulolytic bacteria from decomposting rice straw". Journal of the National Science Foundation of Sri Lanka, Vol. 2, no.1, pp. 25-30, 1995.

[10] K. Muzakhar., Masruroh., Siswoyo., R. Winarsa., and Sutoyo. "Sugarrich hydrolysates of palm oil empty fruit bunch production through two step solid state fermentation and its confersion to ethanol". Advanced Science Letters, Vol. 23, no. 3, pp. 2533-2535, 2017.
[11] N. Nelson. "A photometric adaptation of the somogy method for the determination of glucose". The Journal of Biologycal Chemistry, no. 153, pp. 375- 380, 1994.

[12] R. M. Mairer. "Enviromental Microbiology". Academic Press. Inc. All rights of Reproduction in any form reserved, 2009.

[13] V. Renge., S. Khedkar., and N. R. Nandurkar. "Enzyme synthesis by fermentation method: a review" Sci Rev Chem Comm, Vol. 2, no.4, 2012.

[14] F. J. Baker and R. E. Silverton." Introduction of medical laboratory technology". Butterworth-Heinemann, United Kingdom, 1976.

[15] R. Subramaniyam and R. Vimala. "Solid State and Submerged Fermentation for The Production and Bioactive Substances: a Comparative Study". International Journal of Science and Nature, Vol. 3, no. 3, pp. 480-486, 2012.

[16] S. Mampreet, S. Sawraj, D. Sachin, S. Pankai and U.C. Baneerjee. "Influence of Process Parameters on the Production of Metabolites in Solid State Fermentation". Review Article. Malaysian Journal of Microbiology, Vol. 1, no. 2, 2005.

[17] H. D. L. Bentubo and O. F. Gompertz." Effects of Temperature and Incubation Time on The in Vitro expression of Proteases, Phospolipases, Lipases and DNases by different species of Trichosporon". SpringerPlus, Vol. 3, pp 377, 2014.

[18] K. M. Sharma., R. Kumar., S. Panwar and A. Kumar. "Microbial alkaline proteases: optimization of production parameters and their properties". Journal of Genetic Engineering \& Biotechnology, Vol. 15, no. 1, pp. 115-126, Jun. 2017.

[19] H.H. Murad and H.H. Azzaz. "Microbial Pectinases and Ruminant Nutrition”. Research Journal of Microbiology, Vol. 6, no. 3, pp. 246$269,2011$.

[20] D. Asem., V. V. Leo., A. K. Passari., M. V. Tonsing., J. B. Joshi., S. Uthandi., A. Hashem., E. F. Abd_allah., and B. P. Singh. "Evaluation of Gastrointestinal Bacterial Population for The Production of Holocellulose Enzymes for Biomass Deconstruction". Plos One, Vol. 12, no. 10 , pp 17, Oct. 2017.

[21] E. N. N. Raju and G. Divakar. 2013. Screening and isolation of pectinase producing bacteria from various regions in Bangaladore. International Journal of Research in Pharmaceutical and Biomedical Science, Vol. 4, pp. 151-154.

[22] A. C. Soria., M. Brokt., M. L. Sanz., I. Martinez-Castro. "Comprehensive Sampling ans sampler preparation". Reference Modul in Chemistry, Molecular Sciences and Chemical Engineering, Vol. 4, pp. 213-243, 2012.

[23] G. Grogan. "Practical Biotransformation". Postgraduate Chemistry Series. Chichester: Jhon Willey \& Sons Ltd, 2009.

[24] A. Kumar and N. Garg. "Enzymology: Enzyme Purification”. Devi Ahilya University, India, 2006.

[25] E. Navasivayam., D. John Ravindar., K. Mariappan., A. Jiji., M. Kumar., R. L. Jayaraj." Production of extracellular pectinase by Bacillus cereus isolated from market solid waste". Journal of Bioanalysis \& Biomedicine, Vol. 3, no. 3, pp. 70-75, 2011.

[26] L. Ho and L. Heng. "Xylanase Production by Bacillus substilis in CostEffective Using Soybean Hull as Part of Medium Composition Under Submergd Fermentation (SmF) an Solid State Fermentation (SsF)". Journal of Biodiversity, Bioprospecting and Development, Vol. 2n no. $1,2015$.

[27] W. Yang., F. Meng., J. Peng., P. Han., F. Fang., L. Ma., and B. Cao. "Isolation and Identification of cellulolytic bacterium from the Tibetan pig's intestine and investigation of its cellulase production". Electronic Journal of Biotechnology, Vol. 17, pp. 262-267, 2014

[28] M. Vatanparast., V. Hosseiininaveh., M. Ghadamyari., and S. Minoosajjadian. "Plant Cell Wall Degrading Enzymes, Pectinase and Cellulase, in the Digestive System of The Red Palm Weevil, Rhychophorus ferrugineus (Coleoptera Curculionidae)". Plant Protect, Vol. 50, no. 4. Pp. 190- 198, 2014.

[29] P. K. Robinson." Enzymes: principle and biotechnological applications". Essays in Biochemistry, Vol. 59, pp.1-40.

[30] J. K. Seo., T. S. Park., I. H. Kwon., M. Y. Piao., C. H. Lee and J. K. Ha. "Characterization of cellulolytic and xylanolytic enzymes of Bacillus licheniformis JK7 isolated from the rumen of a native Korean goat”. Asian-Aust JAnim Sci, Vol. 26, pp. 50-58, 2013.

[31] K. Muzakhar. "A consortium of three enzymes: xylanase, arabinofuranosidase, and cellulase from Aspergillus sp. which liquified coffee pulp wastes”. IOP Conf. Seris, Vol. 546, 2019. 